\title{
General Guidelines for Managing Pastures for Dairy Cows 1
}

\author{
L. E. Sollenberger, Y.C. Newman, and J.M.B. Vendramini²
}

\section{Introduction}

The decision to use pasture as a major source of nutrients for milking cows must be accompanied by a strong commitment to properly manage the pasture. Determining soil fertility status, choosing a fertilization program, selecting appropriate forage species, and controlling grazing are important elements of a pasture-management program.

\section{Soil Testing and Pasture Fertilization}

Soil-nutrient status varies widely from field to field on many conventional dairy farms. Soils in "herd pastures" that serve as lounging areas for cattle often are very high in phosphorus and potassium. However, soils from an adjacent field where harvested forage is grown may be low in these nutrients. Soil testing allows identification of soils that are high in nutrients, where primarily nitrogen fertilizer is needed to grow grass, and soils that are low in nutrients, where phosphorus, potassium, and perhaps other nutrients and lime will be needed in addition to nitrogen.

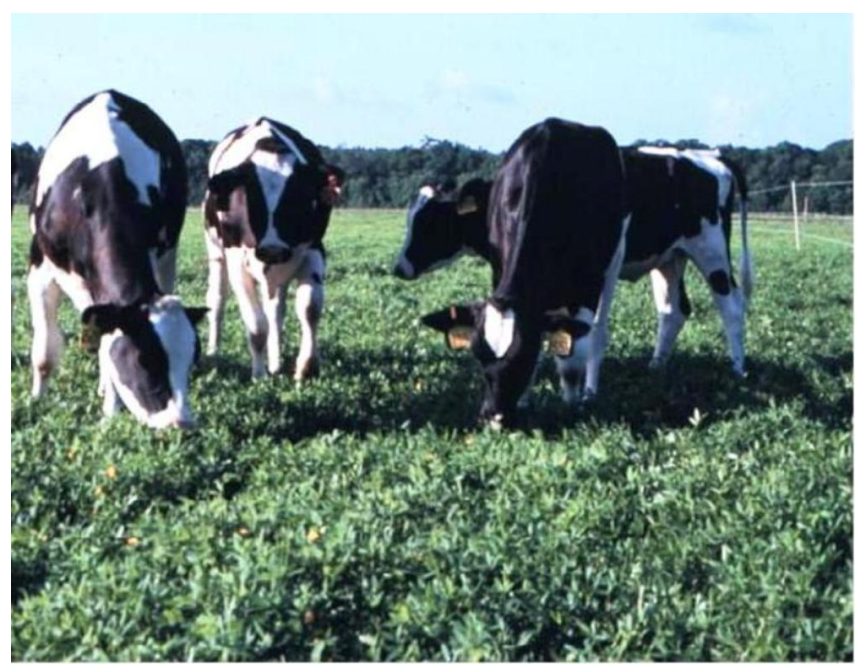

Figure 1. In this 1996 photo, heifers are pictured grazing in a rhizoma peanut pasture at the Beef Research Unit near Gainesville, FL. Credits: L.E. Sollenberger, UF/IFAS.

1. This document is SS-AGR-94, one of a series of the Agronomy Department, Florida Cooperative Extension Service, Institute of Food and Agricultural Sciences, University of Florida. First printed June 1997. Revised February 2006 and June 2009. This publication is a part of the Florida Forage Handbook, an electronic publication of the Agronomy Department. For more information contact Y.C. Newman, editor of the handbook -- ycnew@ufl.edu). Visit the EDIS Website at http://edis.ifas.ufl.edu.

2. L. E. Sollenberger, professor, Agronomy Department; Y.C. Newman, assistant professor, Agronomy Department; and J.M.B. Vendramini, assistant professor, Agronomy Department, Range Cattle Research and Education Center--Ona, FL; Florida Cooperative Extension Service, Institute of Food and Agricultural Sciences, University of Florida, Gainesville, FL.

The Institute of Food and Agricultural Sciences (IFAS) is an Equal Opportunity Institution authorized to provide research, educational information and other services only to individuals and institutions that function with non-discrimination with respect to race, creed, color, religion, age, disability, sex, sexual orientation, marital status, national origin, political opinions or affiliations. U.S. Department of Agriculture, Cooperative Extension Service, University of Florida, IFAS, Florida A. \& M. University Cooperative Extension Program, and Boards of County Commissioners Cooperating. Interim Dean Millie Ferrer. 


\section{How often should grazed pastures be fertilized?}

To answer this question, think about what fertilization does for the pasture. Generally, fertilization increases the yield and/or nutrient density of the forage. In Florida soils, a shortage of nitrogen almost always limits grass yield, so nitrogen is the most-needed fertilizer nutrient in many cases.

Nitrogen is easily leached from sandy soils by heavy rains, so fertilizer applications should be split to minimize leaching losses. When temperature and rainfall are high in summer, monthly applications of nitrogen may be needed to keep the grass growing well and maintain a relatively high crude protein. During other times of the year, fertilization can be less frequent. If there are a relatively large number of cows per acre (a high stocking rate) on the pastures, correspondingly high rates of nitrogen fertilizer will be needed to provide enough grass. Lowering stocking rate will allow for a lower rate of nitrogen. Keep in mind that grazed pastures will require less fertilizer than hay fields because a high proportion of the nutrients consumed by grazing livestock are returned to the pasture in their feces and urine, rather than being harvested and moved off the field, as in a hay operation.

\section{What about phosphorus and potassium?}

Because phosphorus and potassium are generally required at lower rates than nitrogen, phosphorus and potassium can be applied less often than nitrogen. One (for phosphorus) to two (for potassium) applications per year according to the results of soil testing should be adequate. Additional phosphorus and potassium applications may be needed if making multiple cuts of hay. If the soil test report does not recommend these nutrients, do not add them. Using unneeded fertilizer wastes a limited natural resource, costs money, and may hurt the environment.

\section{What $\mathrm{pH}$ is too acidic for grasses?}

Soil $\mathrm{pH}$ can affect growth of forages. Lime is applied to raise the $\mathrm{pH}$ when soils are too acidic. If soil $\mathrm{pH}$ is lower than 5.5, liming of perennial grass pastures is recommended. For economic reasons, apply at least one ton per acre whenever lime is applied. Nitrogen fertilizers containing ammonium forms of nitrogen acidify the soil more than other sources of nitrogen, so the higher the ammonium nitrogen rate the more often lime will be needed. A general rule for heavily fertilized pastures is that liming will be needed every three to five years.

Soil should be tested at least every three years to determine liming requirements. Always test soil before deciding to lime. However, don't overlime because high soil $\mathrm{pH}$ (greater than 6.5-7) leads to plant deficiencies of micronutrients (manganese, zinc, iron, and copper) and poor forage growth.

\section{Choice of Forage Species}

In addition to fertilizer management, choice of forage species is important. The forage species chosen depends upon many things. Two of the most important factors are location in Florida and soil type. North of Orlando, most producers choose bermudagrass, pearl millet, or sorghum-sudangrass hybrids for summer grazing and rye or ryegrass in winter. South of Orlando most producers use either stargrass or bermudagrass in summer and ryegrass in winter.

The hybrid bermudagrasses - Coastal, Callie, and Tifton 85 - do not grow well on wet sites, but common bermudagrass tolerates wet soils well. However, the hybrid bermudagrasses outyield common bermudagrass and are more nutritious. Stargrass is not sufficiently cold-tolerant for North Florida. In South Florida, the area of the state that is south of Orlando, stargrass is better adapted to soils that are wetter than the soils hybrid bermudagrasses can tolerate.

Pearl millet is an annual and best grown on soils that are moderately well drained to well drained. Sorghum-sudangrass hybrids, also annuals, can tolerate wet soils better than pearl millet can. However, young growth of sorghum-sudangrass hybrids after drought or cold can contain prussic acid, a potent toxin, so care is required if this forage is used. Rhizoma peanut is a high quality legume for dryer sites and does not yield as much as the grasses, but doesn't require nitrogen fertilizer. Additionally, rhizoma peanut stands last for many years. 
Annual ryegrass and clovers (red, white, or crimson) are good choices in North Florida for cool-season grazing on moist soils or when irrigation is available to get these forages established. Rye is adapted to dryer North Florida sites, but grows well in a mixture with ryegrass on moderately wet sites. In South Florida, the growing season for cool-season annuals is short and, as a result, these annuals may not be an economical alternative for some producers in that region. Those who use cool-season forages in South Florida generally have greatest success with annual ryegrass.

However, establishment of the annuals (pearl millet, sorghum-sudangrass, and all of the cool-season forages) is risky without irrigation anywhere in Florida. During some years, timely rains will ensure good stands, but in other years rain may not come, and stand failures may occur. Access to irrigation reduces risks associated with grazing dairies.

\section{Grazing Strategies}

\section{Once forages are established, how should they be grazed?}

For most dairy situations, the choice of rotational stocking (also called rotational grazing) is a good one. Cows are moved every 12-24 hours to a new paddock, and the paddock where grazing just ended is given time to rest and regrow before it is grazed again. Advantages of this practice over continuous stocking include better distribution of manure, more consistent diet for the cows, and higher yields and increased longevity of the pasture.

\section{How closely should the pasture be grazed?}

The answer to this question depends upon the forage being used, as well as on production goals for the herd, and on how quickly the pasture will be grazed again. Taller-growing grasses - hybrid bermudagrass, stargrass, and pearl millet - generally should be grazed no lower than a stubble of 6-10 inches. Shorter grasses, such as bahiagrass and common bermudagrass, can be grazed to 2-4 inches.

Grazing close puts more stress on the pasture, removing most of the leaves the plant uses to produce its food. Short rest periods following close grazing will not allow plants time to restore their leaf area. When closely grazed forage is grazed again, these plants are forced to use energy reserves to regrow. As the plant reserves are depleted, plant growth rate slows, and eventually closely grazed plants will die. Close grazing also forces the cows to graze more stem, which reduces digestibility and intake and results in lower milk production.

Stocking rate - one of the most important decisions a pasture manager makes- determines how close the pasture is grazed. The ideal stocking rate in a given situation will be affected by the forage, as well as by weather conditions, fertilization, amount of concentrate being fed to the livestock, and also production goals.

We have found that some ballpark numbers can serve as a starting point for choosing stocking rate. Well fertilized bermudagrass, stargrass, and pearl millet have carried from three to four milk cows per acre during June through September when those cows were receiving approximately $20-25 \mathrm{lb}$ of concentrate per head per day. Rhizoma peanut has carried from two to three cows per acre during the same period when cows were receiving the same amount of concentrate.

However, spring and fall stocking rates are less for all of these forages. When drought conditions hit, stocking rates are much less. Winter pastures carry fewer animals, between one and two animals per acre in many cases. Winter stocking rate may be greater if irrigation is available for drought periods and relatively high rates of nitrogen fertilizer are used.

Someone thinking of starting a grazing operation may ask how many acres of pasture are needed for each cow. If depending almost exclusively on pasture for the forage source, an approximation is one-half acre per cow. Using this ratio, for 600 milk cows at least 300 acres is needed. In summer, less acreage is needed, so excess forage can be baled or ensiled. In late fall through spring, however, more acreage may be needed. If the systems are flexible enough that a cottonseed-hull-based concentrate mix or conserved forage can be fed during times of slow pasture growth, less than one-half acre per cow may be needed. 
Anyone starting with grazing should stock conservatively. Learning to manage a grazing dairy takes time, and starting with too many cows makes the process more difficult. 